\title{
Increasing Quality through Implementing the Quick Response Method to Achieve Competitiveness of the Company'
}

\section{Summary}

Representatives of the European Union as well as particular countries realize that quality has become a decisive factor of competitiveness. Therefore, they intensively support the care for quality at the micro-economic level. It is provided through corporate quality management systems. It is a tool allowing companies to grow constantly through suitable application of modern methods applicable in the corporate management. One of the methods contributing to increasing the quality provided as well as to efficiency of actual processes is the Quick Response method. It is an approach enabling to increase the speed of response to the customers' demands, with reasonable costs spent. Implementation of this method should contribute to fulfilling the basic principles of the quality management and higher competitiveness of the company.

\section{Introduction}

Complex apprehension of the quality is considered not only a competitive advantage but also a productive tool on the way to prosperity (Sysel, 2008). In the European Union, an exceptional attention is paid to the issue of quality. To achieve European competitiveness, quality promotion was included in 1993 in the White Book

${ }^{*}$ Dr, Department of Economy and Management, University of Pardubice, Czechy.

** Dr, Department of Economy and Management, University of Pardubice, Czechy.

${ }^{1}$ The authors thank for the financial support provided by the Grant Agency of the Czech Republic under the project No 402/06/0577 "Increase of Company Performance Efficiency through Differentiated CRM on a Basis of Customer Actual and Potential Value to a Company." 
"Development, Competitiveness and Employment" and the council of ministers approved this initiative. Passed were documents "A European Quality Promotion Policy for Improving European Competitiveness" and "Benchmarking the Competitiveness of European Industry". These became a basis of similar policies in the EU member states. In 1998, "European Quality Charter" was signed in Paris at the European Quality Convent (Sysel, 2008). According to this, European products and services have to be best in order to win, i.e. so that the European continent could prevail at the international market (Sysel, 2008). In the Czech Republic, it was not until the late 1990's that the government started dealing with the quality issue on a considerable scale. In 2000, the government of the Czech Republic passed a document called "National Policy of Quality Promotion" being the first to formulate the relation of the state towards the requirements of the quality development. Quality management systems in the Czech Republic, however, have been developing since 1990's. A major impulse for this tendency were in particular multinational and foreign companies that in searching for local suppliers demanded proofs that the supplying companies are managed credibly and in compliance with practise common abroad. It was an ISO certification that proved it best. In the mid 1990's, dynamic growth was observed in the number of organization introducing the ISO-based quality management system, and that was virtually in all the branches. Nevertheless, the largest number of the certified organizations comprises of automobile industry, electrical engineering, civil engineering and food processing industry branches. Revision of the ISO norms in 2000 approximated these standards even to organizations conducting business in services and recently quality management systems based on these norms are being introduced even in the branches of canteen and public food services, cleaning services, property management and travel business services. In the Czech Republic, more than 7,000 companies have already implemented quality management system on ISO base and successfully underwent the certification (Sysel, 2008). These systems are fully established also in the chemical industry branches. Corroborating this statement may be results of a survey "Implementation of Management Systems" carried out in 2005 in companies associated in the Association of the Chemical Industry. The primary research proved that all the correspondents have implemented the QMS and, with the exception of one, certified it as well. $72 \%$ of respondents stated that they had been utilizing the system for more than 7 years. $21 \%$ of the respondents have been utilizing the QMS for more than 3 years yet less than 7 years. Only $7 \%$ of the respondents have been utilizing the system for less than 3 years (Hyršlová, Špaček, Branská, 2005: 40). It may then be concluded that the management quality concept has been mastered with its principles entering the general knowledge such as customer orientation, process approach, quality spiral, PDCA cycle and the principle of continual improvement. More and more attention is also being paid to implementing measurement of the process efficiency though there are still considerable reserves in this area in our opinion. 


\section{Corporate Quality Management Systems as a Tool to Increase the Company's Competitiveness}

Corporate Quality Management Systems contribute to a considerable extent to the growth of the company's competitiveness. They promote development of a modern process management, i.e. a process management with applied aspects of the quality management, environmental management as well as health and safety management. The objective of thus conceived management is to increase the company's market value through providing (and increasing) the customer value in a way ensuring that the environmental and social impact of the corporate activities are reasonable.

The idea that it is necessary to base quality on the customer and it can be provided only through a system of constantly improving corporate processes is thus well-known. The problem though is that the concept is still being developed of what the customer value actually is and how to manage the corporate process systems so that it was provided. The customer value is created as a set of benefits where particular quality aspects may be of different importance to the costumer. One of the most important attributes of quality appears to be the speed in which the customer value is provided.

The set of benefits for the customer, i.e. the value provided to him, must create a value for the company (Gupta, Lehmann, 2005: 43-47). This simple idea is the base of the modern concept of the differentiated CRM (Customer Relationship Management). According to this approach, it is not enough only to properly segment the portfolio of the company's customers by their needs and shopping behaviour while satisfying the needs but, at the same time, it is necessary to take the value of these segments into account (micro-segments), or as the case may be, of particular customers for the company (Best, 2005: 155-163). Usually it is necessary to estimate the value of individual customers for the company and to adjust the way their serviced according to it. It appears to be absolutely logical that the best quality method of service must be provided to the most valuable, i.e. key customers so that it would come up to their expectations to the largest extent possible. The need for individualization of offers to individual customers then requires such a system of processes that would not only allow it but also actively aid it. The system of processes and their run must be therefore adjusted to thus-conceived work for the company's customers. Usually this means to leave the principle of standard performance of particular corporate processes and set the system so that it enabled individual execution of particular corporate processes and activities.

For the most important, key customers it is possible to establish such a system of service attendance that secures a fast satisfaction of their need. What matters is, however, not only that the company generates speed at the sale itself but that the idea of speed is reflected in the entire value-creation process, or as the case may be, in the whole system of processes. This shall secure higher economic benefits arising not only from higher flexibility but also from higher efficiency of execution of activities. This thus conceived quality management may be aided by the Quick Response method. Its implementation thus contributes to increasing the quality of corporate activities.

The Quick Response (QR) method allows increasing the speed of response to the demands by (individual) customers, and that is with investment of reasonable expenses. 
QR in its classic form is used as a retail strategy allowing through implementation of particular tactics and techniques improvement of material flow between the producer and the retailer (Pernica, 1998: 335-336). As a consequence, it naturally results in decreasing the level of stock. In fact, the method is based of the JIT principle directed at reduction of loses and supplies through supplying raw material and materials in the time required (Grant, 2006: 23). What matters is, however, not only reduction of these losses but also acceleration of the response to the customers' demands through transmitting information back to the supply chain. With full implementation of QR, JIT is applied within the entire Supply Chain.

Quick Response is grounded on information systems and in fact it requires round-theclock monitoring of sales. It forwards information from business segments to the producer that makes use of it and forwards it to its suppliers, or as the case may be, information is transformed so that the supplies could be automatically stocked up towards the individual customers in the chain. Reduction of supplies comes up not only in the distribution chain but in the whole supply chain as a result of the shift of the point to which information get on the actual demands by real customers.

This method of work towards the customers (consumers), however, has its impact in the way other corporate processes are managed, i.e. it assumes performing the entire value-making process in the company. Also other corporate processes must be managed to aid this speed of value-creating process. The thing is that increasing the quality provided to the customer as a consequence of implementation of Quick Response requires higher quality of corporate activities, i.e. implementation of this method has a direct impact to the company's process system. Some activities of ordering process, for instance, may be eliminated, whether it be in the sale or purchase process (with relations tied on the basis of QR also with the supplier). It is usually the order shipping process and transfer of demand but also in relation to the set extent of closeness of cooperation between partners, for example the order confirmation process or production stock managing process. On the other hand, new processes may arise (automatic replenishing of supplies), or as the case may be, their original form gets modified (e.g. the change in information transfer, changes in the way the goods are shipped, etc.).

\section{Impacts of Application of QR Method in the Purchase Process}

Application of the QR method modifies not only the company's process system but it may affect understanding of quality of each single process. To secure quality (and thus also fast) course of each corporate process in an optimal way, it is necessary to:

- define the output and its quality and suitable inputs into the process,

- specify activities of the given process,

- apply other (in fact in the view of Quick Response partial) methods of managing the process and activities taking place within.

If we choose for demonstration of these three basic steps the purchase process, it is necessary to first define its required output. We see the purchase not only as the business act itself but all the preceding and follow-up activities while it results in satisfying 
demands by other corporate processes. The principal objective of purchase is to secure increase of the value added through timely, fluent and economical provision for the required raw materials, materials and services for the needs of the other corporate processes, and that is with respect to the environmental impacts of its activity as well as health and safety at work. Using the Seven R's approach according to literature (Shapiro, Heskett, 1986:6), it may be said that a properly executed purchase should buy the efficiently right inputs, in the right amount, at the right place, in the right time, under the right conditions, for the right customer (in our case internal) and provide the right flows (material as well immaterial) in the follow-up processes according to the needs of particular process teams.

Through suitable inputs into the purchase process upon realization of the Quick Response method may the information on actual sales of the preceding and final link of the chain, joint forecast of demand for a product of the whole chain, plans in the area of material flows of the preceding link (or as the case may be links) of the chain and/or the point of ordering the preceding link of the chain, actual amount of the immediate supplier's supplies and other (traditional) information, such as corporate standards, stock level in the expedition warehouse, work and technological procedures, etc.

In the second step, it is necessary to specify required activities of the process. For the purchase, it may be:

- Purchase planning (means planning of needs, planning of the entire stock level and purchase planning).

- Ordering process or, as the case may be, conclusion of contract (including sending an order, responses to offers, sending orders or, as the case may be, elaboration of a purchase contract draft, business talks, signing a purchase contract).

- Realization of the delivery (usually includes loading with the supplier, transport from the supplier's enterprise, unpacking, reception of goods and quality check).

- Handling of goods and replenishing of the stock.

- Warehousing.

- Delivery from warehouse and delivery of material inputs according to demands of the follow-up processes.

The number and shape of the required activities of the given process will depend on:

- the level of cooperation closeness as arranged especially with the supplier,

- the definition of the output quality (satisfying the consumer of the input, i.e. of the production) of the given process.

The speed of the whole purchase process then depends on the quality of inputs, number and manner of realization of particular activities of the process. Increasing the speed of the given process may be achieved by increasing quality of one or all the aspects.

In the purchase process, optimizing methods and procedures, such as optimization of the delivery size, etc. These methods are in fact, in the view of Quick Response, techniques contributing to fast and quality course of the given process. 


\section{Measuring in the quality management systems as a significant element for permanent improvement}

To secure continual improvement, managers must follow efficiency of the entire process system (of the entire company), i.e. they must solve necessity of particular processes and their mutual interconnection so that this system is able to secure the valuecreating process at reasonable costs. No less important is, however, to pay attention to each single process, in terms of its contribution to creation of the end value (both for the customer and the company's owner). Managers of particular processes (owners of the processes) should take care of suitably set objectives for entrusted processes as well as contingency criteria (measures) through which they will monitor the course of processes and fulfilment of particular set objects. These objectives should be set in order to contribute to value-creating process for the customer and understandably also with respect to the objectives of the other corporate processes. Their setting is a basic precondition for evaluating the process efficiency and its subsequent continual improvement. Criteria defined for monitoring of process efficiency may be identical with these objectives or may be derived from these objectives so that they signal the extent of fulfilment of these objectives.

Upon designing the measures for complex measuring of efficiency of the purchase process, it is possible to work on literature (Nenadál, 1999: 215) where the universal measures (indicators) of process efficiency are divided in the following categories:

- the time when, for instance, the average time of process run is calculated,

- quality as demonstrated by, for instance, the extent of nonconformities in \%, etc.,

- flexibility, thus ability to respond to changes in the process,

- expenses, such as total expenses for the process,

- environmental impact, such as noise level,

- value added.

Furthermore, it is necessary to consider that the proposed criteria should encompass the overall process efficiency as well as it should focus on considering the successfulness of each activity in the purchase process (with respect to needs of identification of narrow points of the process in terms of its efficiency). The process manager should in fact know how particular activities contribute to the final result of the entire process. And finally, the proposed set of criteria should encompass the purchase in view of its quality, environment and health and safety.

In our opinion, a suitable combination of financial and non-financial measures should be used for complex assessment of efficiency of the purchase process or, as the case may be, measures encompassing the both dimensions of performance efficiency, those being:

- dimension of purposefulness (quality including both environmental and health and safety aspects) represented by measures of time, quality, flexibility and environmental impact) and

- dimension of efficiency (represented both by the value added and expenses).

The chosen set of measures should be, however, in compliance with measuring of other partners of the chain cooperating on the QR basis, i.e. the measures should be integrated throughout the enterprises to enable continual improvement by the spirit of 
TOC principles (Theory of Constraints). Only such changes should be realized that make some sense and that shall actually pay off. This means to trace the weak link in terms of efficiency not only in the company but in the entire chain and to reinforce this chain until efficiency of another limiting factor is achieved. This procedure should result in step-bystep (gradual) improvement of the company's performance efficiency according to the KAIZEN approach. However, there may appear such market opportunities and/or new management methods that will be impossible to utilize (or as the case may, to realize) only through gradual improving. Then it will be necessary to approach once again a radical change in setting of the process system, i.e. reengineering.

A properly set measuring system secures providing quality and continual improving without the necessity of detailed description of particular processes that may show a high variability.

\section{Conclusion}

The QR method helps to incorporate the idea of "quick response" into the system of corporate processes and may entail extraordinary flexibility of the entire company. It is highly probable that this ability will become a source of permanent and difficult-to-imitate competitive advantages. In other words, implementation of QR in this way shall contribute to increasing the quality of the corporate management as a tool of increasing the company's performance. This then means that the QR method should not only be accepted by the corporate quality management system but also fully supported by it. If the corporate systems are this flexible in terms of implementation of new techniques, principles and approaches, they will help the companies to maintain and even develop their market position while successfully resisting the competitive pressures. In such case, it is also in the interest of individual countries to promote their development, which does not exclude parallel use of tools for promotion of care for quality at the micro-economic level. All these initiatives by the government then increase a chance of entrepreneurial subjects to succeed at the global markets.

\section{References}

Best R.J., Market-Based Management: Strategies for Growing Customer Value and Profitability, Pearson and Prentice Hall, New Jersey 2005.

Grant D.B. at al., Fundamentals of Logistics Management, McGraw-Hill Education, New York 2006.

Gupta S., Lehmann D. R., Managing Customers as Investments: the Strategic Value of Customers in the Long Run, Upper Saddle River: Wharton School Publishing, 2005.

Hyršlová J., Branská L., Špaček L., The Current Stage of Management Systems Implementation in the Czech Chemical Companies (in Czech), "Vedecké listy" 2006, nr 4 (II).

Nenadál J., Measurement in the Quality Management Systems [in Czech], East Publishing, Praha 1999.

Pernica P., Logistics Management [in Czech], Radix, Praha 1998.

Shapiro R.D., Heskett J.L., Logistics Strategy: Cases and Concepts, St. Paul, Minn. West, 1986.

Sysel J., Quality Management Conception [in Czech], http://www.cestovni-ruch.cz/hotelieri/iso9000a. php, 26.11.2008. 


\section{Wzrost jakości poprzez wdrażanie metody szybkiej odpowiedzi w celu poprawy konkurencyjności przedsiębiorstwa}

\section{Streszczenie}

W wielu krajach Unii Europejskiej, jak $i$ w poszczególnych przedsiębiorstwach nastawienie się na poprawe jakości działania jest decydującym czynnikiem wzmacniania pozycji konkurencyjnej podmiotów ekonomicznych. Jest to osiagane poprzez właściwie dobrane systemy zarzqdzania jakościq. Jednym z nich jest metoda szybkiej odpowiedzi. Polega ona na szybkim reagowaniu na oczekiwania odbiorców przy jednoczesnym poszukiwania możliwości dotarcia z oferta po jak najniższych kosztach. Artykuł opisuję tę metodę zarzadzania jakościq w kontekście jej wykorzystania do poprawy konkurencyjności przedsiębiorstwa. 